\title{
STEPPING-STONES TO SECURITY: AN ANALYSIS OF THE SAFE THIRD COUNTRY AGREEMENT
}

\author{
by
}

Rosemary Elizabeth Legge

Honours BA, Brock University, 2005

\author{
A Major Research Paper \\ presented to Ryerson University
}

In partial fulfillment of the requirements for the degree of

\author{
Master of Arts \\ in the program of \\ Immigration and Settlement Studies
}

Toronto, Ontario, Canada 2006

CC Rosemary Elizabeth Legge, 2006 
UMI Number: EC53438

\section{INFORMATION TO USERS}

The quality of this reproduction is dependent upon the quality of the copy submitted. Broken or indistinct print, colored or poor quality illustrations and photographs, print bleed-through, substandard margins, and improper alignment can adversely affect reproduction.

In the unlikely event that the author did not send a complete manuscript and there are missing pages, these will be noted. Also, if unauthorized copyright material had to be removed, a note will indicate the deletion.

\section{$\mathrm{UMI}^{\circ}$}

UMI Microform EC53438

Copyright 2009 by ProQuest LLC

All rights reserved. This microform edition is protected against unauthorized copying under Title 17, United States Code.

ProQuest LLC

789 East Eisenhower Parkway

P.O. Box 1346

Ann Arbor, MI 48106-1346 
I hereby declare that I am the sole author of this major research paper.

I authorize Ryerson University to lend this paper to other institutions or individuals for the purpose of scholarly research.

I further authorize Ryerson University to reproduce this paper by photocopying or by other means, in total or in part, at the request of other institutions or individuals for the purpose of scholarly research. 


\title{
STEPPING-STONES TO SECURITY: AN ANALYSIS OF THE SAFE THIRD COUNTRY AGREEMENT
}

\author{
(C) Rosemary Legge, 2006 \\ Master of Arts \\ Immigration and Settlement Studies \\ Ryerson University
}

\begin{abstract}
This major research paper examines the impacts of the Safe Third Country Agreement on North American cross border relations and on potential refugee claimants seeking to file status claims in Canada and the United States. The Safe Third Country Agreement between Canada and the United States was implemented on 29 December 2004 and will be examined in light of its relations to state security and human security. The paper will seek to address how the Safe Third Country Agreement has impacted bilateral communications between Canada and the United States, how the Agreement has worked in a post-9/11 era, and how Canada and the United States have maintained their international obligations. Similarly, this research paper will examine how the Agreement has impacted refugee claimants attempting to come to Canada, as well as the potential risks and challenges that the Agreement presents to refugees and those working with them.
\end{abstract}

Key Words: Safe Third Country Agreement, state security, human security, cross-border relations, refugee claimants 


\section{Acknowledgements}

I would like to thank all those who agreed to be interviewed for this major research paper. At this time, I would like to acknowledge and thank my supervisor Professor Arne Kislenko for his dedication to working with me and helping me finish this major research paper. I would also like to thank my parents, family, and friends for their continued support. Thank you to those individuals and organizations who allowed me to interview them and who wish to remain anonymous. I would also like to acknowledge the following individuals and organizations and thank them for the information they provided:

Lynn Hannigan - Director, Casa El Norte

Daiva Kelertas - Settlement Counselor, Fort Erie Multicultural Centre

Guidy Mamann - Mamann and Associates

Maria R. Rosciglione - Staff Attorney, Casa Vive

Bruce Scoffield - Director, Policy Development Refugees, Citizenship and Immigration Canada 


\section{Table of Contents}

Introduction $\quad 1$

$\begin{array}{ll}\text { Methodology } & 6\end{array}$

Definition of Terms

$\begin{array}{lr}\text { Historical Background } & 12\end{array}$

$\begin{array}{lr}\text { Issues of the State } & 18\end{array}$

Issues Relating to Refugee Claimants $\quad 30$

$\begin{array}{ll}\text { Conclusion } & 43\end{array}$

Appendix A: Literature Review $\quad 47$

$\begin{array}{lr}\text { Bibliography } & 54\end{array}$ 
The phenomenon of mass migrations of people did not present itself within the past 100 years, nor did it occur directly as a result of war or violence within one isolated region. Mass migration has been occurring for centuries, but it was only after large numbers of displaced persons began to accumulate in Europe after the First and Second World Wars that the international community began to realize a refugee crisis was beginning to take shape. The refugee crisis has not slowed, and the gathering of resources and funds for displaced people has become a primary concern for countries in the international community, which act as safe havens for refugees. Nevertheless, it would appear that calls to create a viable and long-term solution to the refugee crisis will continue despite resistance and repeated insistence that states must take primary responsibility for their own.

The shifting of responsibility for displaced persons from source countries to external receiving countries brings forth many questions. Who has the true responsibility for resettling, giving refuge, and accepting displaced people? Is it possible for a receiving country to properly secure both its territory and its citizens while at the same time meeting its international obligations? In addition, how can a state protect its sovereignty if it continuously allows outsiders to penetrate its borders and use the system established to take care of its own citizens? These are the types of questions that governments of receiving countries and source countries must ask themselves when preparing to experience population migration. There are also questions that refugee claimants must consider when attempting to move from one country to another. For example, which state will be the most likely to accept a claim of refugee status? Which state offers the best opportunity to begin life over again? Is a refugee claimant able to reach that country safely? What laws and regulations does the intended receiving state have in place that will either hinder or create opportunities for acceptance? These questions, and many more, are all taken into consideration when developing a flight plan from a country, developing legislations and policies to regulate migrant movement, and in providing safeguards for both receiving states and the migrants themselves.

Refugee claimants face new challenges and risks when they present themselves at the borders of receiving states, while governments face large backlogs of claims and new problems that come with 
continuous migration. In order to meet such challenges, and to accommodate calls for better responsibility sharing and border management, the American and Canadian governments created the Safe Third Country Agreement. The Agreement was implemented on 29 December 2004 and has proven to be an issue of contention in the area of refugee resettlement. The Safe Third Country Agreement is a contentious issue between non-governmental organizations, immigration lawyers, refugee advocates, and the governments of Canada and the United States. Human migration is of concern to all parties involved, and yet changes in refugee policy have been met with disapproval and distrust. Canada and the United States are concerned not only with migration, but also with the legitimacy of potential refugee claimants. While the government believes that a Safe Third Country Agreement will bring more efficiency to an already overloaded refugee determination system, refugee advocates, and some in the settlement sector, believe that the Agreement will prove to be harmful to the rights and lives of claimants seeking refuge in North America. Either way, the implementation of the Safe Third Country Agreement may prove to revolutionize the refugee determination systems in both Canada and the United States by opening the door for more bilateral determination and control as both governments seek to regulate those who are to be granted refugee status.

One key change in the twentieth century was the move by governments towards regulating migration, in particular immigration, and towards defining those who were to be granted the special status of refugees. This change is fundamentally linked to the subject of [this volume]: the question of how governments regulate immigration and define categories of immigrant has, over time, led people to view migration as an issue related to the security both of the state and of existing citizens and legal residents ${ }^{1}$.

As mentioned above, the twentieth century has ushered in new methods of regulating the flow of migration. Host countries receiving refugees, both in the developed and the developing world, have in recent years begun to establish more effective barriers in order to protect themselves from being overrun with migrant populations. Whereas humanitarian concerns drove the initial outpouring of refugee reception in most parts of the world, there is now an almost urgent shift towards firmly establishing the

\footnotetext{
${ }^{1}$ Edward Newman, "Refugees, International Security, and Human Vulnerability: Introduction and Survey," in Refugees and Forced Displacement: International Security, Human Vulnerability, and the State (eds.) Edward Newman and Joanne van Selm (New York: United Nations University Press, 2003): 3-4.
} 
security of the state and its citizens before entitling those seeking asylum to any form of protection. It is within this context that the bilateral Safe Third Country Agreement between Canada and the United States will be examined. The increased importance, in this post-9/11 era, of state security has driven the two countries into creating bilateral border policies that will work to better govern the flow of refugees. In theory, such a policy would work to benefit both the state and the potential refugee claimant in areas of border management, protection, and responsibility. In practice, however, such policies have arguably worked in favour of the state rather than the potential refugee claimant. The Safe Third Country Agreement is an ideal example of this recent transition in refugee and security discourse, as it encompasses the interests of border management and responsibility sharing as its primary functions, and the interests of refugee protection as its secondary function. While both Canada and the United States purport that that the new Agreement continues to offer asylum seekers the highest degree of humanitarian protection, there are concerns about whether the Agreement is truly protecting the state or refugee claimants.

Canada and the United States have become two of the main destination countries for immigrants and refugee claimants. In the past fifteen years, more than 131,000 refugee claims were made in Canada at land borders alone ${ }^{2}$. In the United States in 2004, 75, 536 applications were filed for refugee status and 52,835 persons were admitted to the United States as refugees ${ }^{3}$. Large numbers of people choosing North America as their primary destination for protection has become a cause for concern for both Canada and the United States. It has become imperative for both nations to create refugee policies that reflect both the interests of the state and the international community. In order to address these issues, a general examination of the Safe Third Country Agreement will be conducted with a focus on two main areas: the affects of the Agreement in both Canada and the United States with regards to cross border

\footnotetext{
2 Canadian Council for Refugees, "Closing the Front Door on Refugees: Report on the First year of the Safe Third Country Agreement," (Montreal: Canadian Council for Refugees, December 2005): 1 .

${ }^{3}$ Nancy F. Rytina, "Applicants and Admissions to United States: 2004 Annual Flow Report September 2005" (United States Department of Homeland Security - Office of Immigration Statistics - Management Directorate); Retrieved from http://www.uscis.gov/graphics/shared/statistics/publications/refugeeflowreport2004.pdf on 2 June 2006,1 .
} 
relations, and how the Safe Third Country Agreement has impacted refugees attempting to enter North America. To address these two main issues, a brief history of the Safe Third Country Agreement in Canadian legislation will be provided to explain why and how it came into existence.

More specifically, the objectives of this research paper will be to address the impacts of the Agreement on Canada-US relations with regards to security, joint border policies, and each nations refugee determination policy. This research paper will also examine the impacts of the Agreement on refugees applying for status in North America via land border crossings, and analyze the potential risks and challenges that the Agreement brings. The above issues will be addressed by providing a brief review of the available literature on the Safe Third Country Agreement, which will discuss the main themes that presented themselves during the research process. Following this, this paper will examine issues of the state, including what benefits the Safe Third Country Agreement brings to the parties involved, the risks to the state, and state security. Secondly, issues surrounding refugee concerns and the Agreement will be provided. This will include a discussion of human security, illegal immigration, and the effects of the Agreement on the number of people successfully making claims in Canada. By examining the Agreement from both a state and a humanitarian perspective, it is hoped that a balanced analysis of the potential impacts that the new policy presents will be given. It is important to provide a balanced assessment in order to conclude if the Agreement has the potential to be of help or hindrance in managing the CanadaUS border.

Studying the impact of the Safe Third Country Agreement on cross border relations and on refugee claimants seeking protection is important for several reasons. First, it allows for greater understanding of the territorial and political aspects that drive both Canada and the United States to place domestic security concerns ahead of international concerns. It also allows one to understand why both governments are concerned about protecting their countries from potentially fraudulent claims. By examining the Agreement in both a historical and contemporary context, it may be possible to determine if a safe third country policy will protect international and North American interests at the same time. Examining the tenets of the Agreement and the consequences of its implementation allows the researcher 
to further explore the argument that there has been a shift from the protection of refugee claimants to protection from them ${ }^{4}$. Conducting a thorough study of the impact of safe third country policies will also determine whether such a policy follows the philosophical auspices of United Nations doctrine, and whether the policy was formed in consideration of humanitarian needs.

In order to fully research and explore the above-mentioned issues, several methods were used. Quantitative and qualitative research from various resources was utilized to allow for a balanced examination of various governments, academic, and advocacy groups dealing with refugees and the framework of the Safe Third Country Agreement. Quantitative analysis was drawn from data providing statistics on refugees entering North America before and after the implementation of the Safe Third Country Agreement. Such analysis came from sources such as Statistics Canada, non-governmental agencies, and the government resources. Qualitative analysis was taken from interviews with government officials, non-governmental employees, immigration lawyers, and settlement workers, as well as government resources, and reviews of academic and scholarly resources. A study of the Safe Third Country Agreement, the Canadian Charter of Rights and Freedoms, and the 1951 Convention Relating to the Status of Refugees helped to clearly define the obligations, rights, and duties of states in providing refugee asylum. After reviewing the available literature, it is hoped that the important issues relating to state responsibility and refugee protection will appear. Primary research coupled with secondary research allowed for an understanding of the social implications of the Safe Third Country Agreement, as well as for an understanding of the relevant political aspects. Understanding North American refugee flows could help explain why a safe country policy was initiated, and what has happened to the refugee flow post-implementation.

Perhaps the most important aspect of the major research paper findings will come from the primary research collected through interviews. In this particular case, there were three different types or groups of people interviewed in order to gather separate perspectives on the issues relating to the Safe Third Country Agreement. The three groups included members of the federal and provincial governments

\footnotetext{
${ }^{4}$ Newman, 7.
} 
in both the immigration sector and in parliament. Also included were Canadian and American immigration lawyers, as well as employees and settlement staff from non-governmental organizations. Several attempts were made to interview Canada Border Service agents, but to no avail. However, an interview was obtained from a director within Citizenship and Immigration Canada ${ }^{5}$. As some of these interviews were difficult to obtain in person, it was necessary to conduct them via email or telephone. However, all possible means of having interviews face to face were taken. While researching this topic, the researcher concluded that refugees themselves may not be a primary resource of qualitative research because they would be considered a vulnerable and potentially biased population. Therefore, it is not recommended at this point to collect data from any such group. Overall, by combining quantitative data analysis with in-depth qualitative analysis of both primary and secondary sources, it is hoped that a balanced and unbiased paper will be presented.

Studying the Safe Third Country Agreement and the nature of how it protects requires employing several key theoretical frameworks. In this particular instance, the Agreement will be examined from a primarily political framework, with more specific theories stemming from areas of security, human rights, and humanitarian concerns. From a political framework, political, territorial, and social aspects of the Safe Third Country Agreement can be discussed. It is important to discuss these three aspects of the policy because they are interconnected in the framing of the policy, relayed in the outcomes of the policy, and they each serve to influence the framing of public opinions towards receiving refugees. With respect to matters of security, human rights, and humanitarian concerns, there will be a focus on the duties of each state as signatories of the United Nations 1951 Convention Relating to the Status of Refugees and of the 1967 Protocol Relating to the Status of Refugees. There is an argumentative position that claims that under a realist framework, governments are obligated to consider the interests of their citizens first, and that a nation's obligations under international rights conventions need not go beyond international norms ${ }^{6}$.

\footnotetext{
${ }^{5}$ Due to confidentiality requirements, some of the names of people interviewed in each category will not be released.

${ }^{6}$ Stephen Gallagher, “Canada's Dysfunctional Refugee Determination System: Canadian Asylum Policy from a Comparative Perspective," Public Policy Sources, No. 78 (December 2003): 22.
} 
While it may be true that states should consider the needs of their citizens first, it is also necessary for states that are signatories of international conventions, and have the means, should attempt to go beyond international norms in response to the international refugee crisis. They should attempt this because it would work to ease the international refugee crisis in the short term as unstable nations work to solve their problems and create long-term solutions for population migration. Both Canada and the United States are signatories of the 1951 Convention, thus obligating them to follow the norms and laws put forth in said document. Acting in such a manner would set international standards, thus allowing other signatories to see that their participation is needed and that it is helpful. While the context and degree of the crisis is continuously changing, this does not mean that individuals are no longer in need of help.

There exists within the literature regarding the Safe Third Country Agreement and refugee policy a security discourse with a dual focus: state security and human security. Within the context of this research, a theoretical framework involving security is included. For the purposes of this paper and for future research, state security will be defined as the protection of central values and the basic means of survival, the ultimate obligation of governments to ensure the protection of the nation state ${ }^{7}$, and of defending a territory against, and deterring, anything or anyone deemed an external threat to a nation ${ }^{8}$. The central values mentioned above have been determined by the Canadian government to be equality, respect for cultural differences, freedom, peace, and law and order ${ }^{9}$. It can be argued that state security must also encompass political, social, and economic interests in order to meet the needs and demands of both domestic and international agendas.

These same interests are also apart of human security. Within refugee policy discourse and in this paper, human security will be defined as being concerned with the protection of people from critical dangers, without regard of their physical location inside or outside of a state, or whether the threat is

\footnotetext{
${ }^{7}$ Astri Suhrke, "Human Security and the Protection of Refugees," in Refugees and Forced Displacement: International Security, Human Vulnerability, and the State (eds.) Edward Newman and Joanne van Selm (New York: United Nations University Press, 2003): 93-94.

${ }^{8}$ Newman, 11.

9 Citizenship and Immigration Canada, “A Look at Canada: What Does Canadian Citizenship Mean?” Canada (1 April 2005); Retrieved from http://www.cic.gc.ca/English/citizen/look/look-02e.html on 2 September 2006, 1.
} 
direct or structural. Human security itself is typically human-centered with a focus on individuals or communal groups, with a security-oriented framework in which emphasis is placed on freedom from fear, threat, and danger ${ }^{10}$. Threats of fear and danger may arise when a state becomes unstable due to economic, social, or political unrest, or due to environmental disasters. People may also face threats of fear and danger from militia groups, governments, religious groups, and others, based upon their standing in society or beliefs in certain practices that oppose states norms. The Safe Third Country Agreement is a key document in preserving the basics of human and state security.

Before analyzing and discussing the broader aspects of Canadian refugee policy and its impacts on North American relations and refugees, it is important to understand exactly who will be discussed. Being discussed within the literature are refugees and refugee claimants. A refugee, according to the 1951 United Nations High Commission for Refugees, can be defined as:

A person who, owing to a well-founded fear of being persecuted for reasons of race, religion, nationality, membership of a particular social group or political opinion, is outside the country of his nationality and is unable, or owing to such fear, is unwilling to avail himself of the protection of that country; or who, not having a nationality and being outside the country of his former habitual residence as a result of such events, is unable or, owing to such fear, is unwilling to return to it ${ }^{11}$.

This specific definition takes into consideration humanitarian, ethical, legal, and political issues of both the state and the individual. Some sources, such as the 1969 Organization of African Unity Convention of the Specific Aspects of Refugee Problems in Africa, and the 1984 Cartagena Declaration, have broadened the term to include victims of armed conflict and violence who have been forced to cross international borders in order to seek safety ${ }^{12}$. The term refugee has been expanded by countries such as Canada to include victims of generalized states of violence and events such as famine and natural disasters that

\footnotetext{
${ }^{10}$ Newman, 15.

11 Office of the High Commissioner for Human Rights, "Convention Relating to the Status of Refugees," United Nations High Commissioner for Refugees, July 1951; Retrieved from http://www.unhcr.ch/html/menu3/b/o c ref.htm on 11 April 2006.

12 Fitzpatrick, 5.
} 
disturb public order ${ }^{13}$. As can be seen, the definition of a refugee is controversial and complex, but within the context being set forth, the term refugee will primarily refer to the definition created by the UNHCR.

A refugee claimant, in comparison to a refugee, is someone who enters Canada by boat, airplane, or on foot, and declare themselves to be refugees. In order to stay in Canada, a refugee claimant must make their claim to the Immigration and Refugee Board. While a refugee claimant is allowed to collect welfare and seek work, they are not permanent residents ${ }^{14}$. A refugee is someone given permanent resident status, while a refugee claimant is not granted that same status until the claim has been approved. It is also necessary to distinguish between a refugee and an asylum seeker. The terms refugee and asylum seeker are used interchangeably in refugee policy discourse, including this paper, depending upon which source is being cited. It has been found within the research that the term asylum seeker is used predominately in American discourse when referring to refugee claimants, and the term refugee is used predominately in Canadian sources.

At this point, it is important to determine what the term persecution means in order to fully understand the contexts in which the UNHCR, Canada, and the United States operate when determining who requires protection. The term persecution, when used in relation to the UNHCR definition of a Convention refugee, relates to any actions that deny human dignity in key ways through systemic or sustained denial of person's basic human rights. Important to this definition are the extents to which a person deserves international protection because such protection may not be available in the country of origin. While persecution has not yet been legally defined, the above definition has been based on persistent and consistent patters of abuse, intervention, and intolerance occurring throughout the world ${ }^{15}$. By defining the term persecution, it is hoped that a better understanding of the basis for which refugee claimants are accepted or denied will be gained.

${ }^{13}$ Matthew Gibney, The Ethics and Politics of Asylum: Liberal Democracy and the Response to Refugees (Cambridge: Cambridge University Press, 2004): 7.

14 June Chua, "Becoming Canadian," Canadian Broadcasting Corporation, (2002): Retrieved from http://www.cbc.ca/becomingcanadian/refugee.html on 2 September 2006.

${ }^{15}$ David J. Whittaker, Asylum Seekers and Refugees in the Contemporary World (NY: Routledge, 2005): 8. 
Finally, it is necessary to define what a safe third country policy is, what the objectives of such a policy include, and how Canada and the United States came to implement such a policy. Safe third country policies were first introduced in the European Union as a method to prevent multiple applications for asylum in several states, either simultaneously or successively ${ }^{16}$. Safe third country policies indicate that each refugee claim application should be examined by a single state and that responsibility rests within that state to make a decision regarding refugee status. The main objective of such a policy is to create better management of land border ports of entry and to restrict the opportunities that refugee claimants have for asylum shopping. Overall, the concept of a safe country of asylum created two main sub-concepts that have become apart of the safe country discourse: first host countries and third host countries $^{17}$. The first host country is the country where a refugee claimant first arrives that has been deemed one of safety. The third host country is the second country that a refugee claimant has determined as the destination country of choice. Ideally, safe third countries were:

To respect the principle of nonrefoulement, and they were countries to which asylum seekers could be returned if that state's laws and practices established that they would be allowed to return or that they would have the right to have the merits of their claims determined in that country ${ }^{18}$.

Upon further research, it will be determined whether Canada could claim the United States as a safe third country or visa versa. One aspect which makes such a claim suspect is the failure or reluctance of the United States to sign the 1967 Protocol Relating to the Status of Refugees, as well as other variations in refugee policy protocol in the U.S. In the course of researching and examining the North American Safe Third Country Agreement, it is important to understand the compatibility of the Agreement under the auspices of the United Nations High Commission on Refugees.

Based upon the European model, Canada, during the 1970's and 1980's, became enamored with the idea of creating a safe third country clause within its federal immigration policy. The policy was first

\footnotetext{
${ }^{16}$ Nazare Albuquerque Abell, "Safe Country Provisions in Canada and in the European Union: A Critical Assessment," The International Migration Review, Vol. 31, Issue 3 (Fall 1997): 570.

17 Abell, 570 .

18 Abell, 573.
} 
introduced in 1988 within Canadian immigration legislation. The central idea surrounding the policy's inclusion was to stop the practice of asylum shopping, which occurs when a refugee claimant travels through two or more countries, and due to rejection, personal choice, or to avoid refoulement, chooses Canada as the country of final destination ${ }^{19}$. Although the clause was not immediately implemented, its presence, and the influence of European developments in safe country policies, has arguably persuaded the Canadian government to change immigration policies towards refugees. With a backlog over 50,000 claims, the initial use of a safe third country policy was a defense against such overload ${ }^{20}$. It was not until after many discussions with the American government about bilateral border management policies, along with demands for increased border security and pressure from Washington, that Canada began to seriously consider implementing the safe third country clause.

The events of 11 September 2001, which will be discussed in further detail in relation to state security, also influenced Canada and the United States to come to an agreement over the need for increased border security. However, both countries had been discussing the Safe Third Country Agreement and the need for such security measures for several years before 11 September 2001. For example, in February of 1995, Prime Minister Chrétien and President Clinton created the Canada-US Accord on Our Shared Borders, which included a provision for implementing a safe third country policy $^{21}$. Further, in 1997, the Canadian government launched the Border Vision Initiative, which facilitated information sharing and coordination between Canadian and American customs and immigration authorities. Finally, in 1999, the Canadian government began pressuring Washington for joint measures to improve management of the shared border, and began revisiting strategies for dealing with the United States. These discussions and pressures resulted in the formation of the Canada-United States Partnership Forum that was designed to foster dialogue among governments, border communities,

19 Abell, 570.

${ }^{20}$ Gallagher, 13-14.

${ }^{21}$ Howard Adelman, "Refugees and Border Security Post-September 11," Refuge, Vol. 20, No. 4 (August 2002 ): 9. 
and other stakeholders on border management and policies ${ }^{22}$. These policies and ideas were developed in tandem with concerns regarding national and international security and world events. In October 1999, Prime Minister Chrétien and President Clinton met to confirm a set of guiding principles that would help to increase Canada-US border cooperation ${ }^{23}$. These principles meant that a restructuring to the approaches and handling of bilateral border control would take place. The first such restructuring came in the form of the US-Canada Smart Border/30 Point Action Plan on 12 December 2001. The Smart Border Action Plan centred around four main pillars: the secure flow of people, the secure flow of goods, forming a secure infrastructure, and increased information sharing and coordination in the enforcement of these objectives ${ }^{24}$. It is possible to argue that the realization stronger border control was needed was not merely an afterthought of both governments after 11 September 2001, but that the events of that day brought the issue into the public eye, thus creating an opportunity for both governments to introduce and implement their joint border ideas.

The ultimate culmination of joint agreements that addressed concerns of state security, human security, and the notion of protection, came through the ratification and implementation of the Safe Third Country Agreement. Canada's primary reasoning for implementing such an agreement was that approximately one third of Canada's yearly refugee claimants passed through the United States before applying for entry into Canada ${ }^{25}$. This means that border management and concern over the high number of refugee claimants entering Canada from the U.S. were broad and systemic issues that needed to be addressed. Even though 11 September 2001 was influential in forming public and government opinion on refugee management, it was not the catalyst for enforcing the Agreement. Canada, arguably, was seeking

\footnotetext{
${ }^{22}$ Donald Barry, “Managing Canada-US Relations in the Post-9/11 Era: Do We Need a Big Idea?” Policy Papers on the Americas Centre for Strategic and International Studies (CSIS) Vol. XIV, Study 11, (November 2003): 8.

${ }^{23}$ Centre for Research and Information on Canada, "Canada-US Border," Centre for Research and Information on Canada (CRIC); Retrieved from http://www.cric.ca/en_html/guide/border/border.html on 4 September 2006.

${ }^{24}$ The White House - Office of the Press Secretary, "US-Canada Smart Border/30 Point Action Plan," 6 December 2002, [press release]; Retrieved from http://www.whitehouse.gov/news/releases/2002/12/2002/206-1.html on 20 July 2006, 1.

${ }^{25}$ Harvard Law School, "Bordering on Failure: The U.S.-Canada Safe Third Country Agreement Fifteen Months after Implementation," Harvard Law School Student Advocates for Human Rights, The International Human Rights Clinic, Human Rights Program, Harvard Immigration and Refugee Clinical Program, March 2006, 10.
} 
to slow down the number of refugee claimants entering the country for reasons of security, logistical and numerical purposes, and the governments concern that many refugee claimants coming from the U.S. were fraudulent. During this time, the American government refused to entertain such collaboration with Canada, but directly after the $9 / 11$ attacks, Washington responded positively to implementation of the Agreement. The American government accepted Canada's proposed Agreement partially to realize high priority counterterrorism measures ${ }^{26}$, and partially to take steps forward in controlling immigration into North America. Furthering rationale in both countries for ratifying and implementing the Agreement stemmed from developments in the international community. Specifically, issues such as the international smuggling industry, the absence of proper screening, and the lack of restrictions on social benefits received by refugee claimants in Canada, drew both Canada and the United States into the joint security agreement $^{27}$. In all, each of the previous joint declarations and agreements, along with the events of 11 September 2001, acted as stepping-stones to the creation of the Safe Third Country Agreement

The objective of the Safe Third Country Agreement is to create an effective measure of control, necessary to better manage access to Canada's refugee determination system. In fact, the Agreement will enhance the orderly handling of refugee claims and strengthen public confidence in the integrity of the asylum systems of both countries ${ }^{28}$.

Strengthening public confidence in the refugee determination systems of North America, enhancing the management of refugee claims filed in both countries, and creating effective measures of control have become central focuses of state security dialogue in the past five years. The Safe Third Country Agreement is supposed to accomplish two main goals: the allocation of responsibility between Canada and the United States, whereby one country assumes responsibility for processing the claims of certain refugee claimants; and the enhancement of the two nations' abilities to manage refugee claims brought by persons crossing the common borders ${ }^{29}$. The Agreement also attempts to address the

\footnotetext{
${ }^{26}$ Harvard Law School, 10.

27 Gallagher, 17.

${ }^{28}$ Citizenship and Immigration Canada, "Safe Third Country Agreement Comes Into Force Today," 29 December 2004, [press release]; Retrieved from http://www.cic.gc.ca/english/press/04/0420-pre.html on 6 June 2006, 1.

${ }^{29}$ Press Office of the United States Department of Homeland Security, "United States and Canada Implement Safe Third Country Agreement on Asylum," 29 December 2004, U.S. Citizenship and Immigration Services, [press release]; Retrieved from http://www.uscis.gov/graphics/publicaffairs/newsrels/Safe-12-29-94.pdf on 26 June 2006.
} 
international legal obligations that Canada and the United States have as parties to the Convention Against Torture, and other Cruel, Inhuman or Degrading Treatment or Punishment, to the 1951 Convention Relating to the Status of Refugees, and to the Protocol Relating to the Status of Refugees. There is a clause within the Agreement that claims both Canada and the United States have mutual obligations to promote and protect human rights and fundamental freedoms $\mathrm{s}^{30}$. While the Agreement only applies at land border ports of entry, it has still become an effective tool for instilling a more rigid approach to refugee protection. The Agreement places responsibility for allotting protection to a refugee claimant with the state, yet attempts to ensure that the state is able to maintain it sovereignty and security.

This has been accomplished through four main exceptions under which a person can now attempt to claim refugee status. The central foundations of the Safe Third Country Agreement are based on Article 4:2a of the Agreement. This section states that the responsibility for determining the refugee status claim of any person who makes a claim in a territory of one of the Parties will rest with the receiving country and not the country of last presence. The country of last presence refers to the country in which a claimant was physically present prior to making a claim at a land border point of entry. The receiving country, either Canada or the United States, must determine if the claimant has in that country at least one family member who has had a refugee claim granted, or who has been given lawful status other than as a visitor. Failing that, the receiving country may determine a claimant to be acceptable if he or she has at least one family member who is at least 18 years of age, and is legally allowed to pursue a claim in the receiving country's refugee determination system and has a claim pending in said country. Also, a claimant may be accepted by the receiving nation if he or she is an unaccompanied minor, if they arrived in the receiving country with a valid visa or admission document issued by the receiving state, or if they were not required to obtain a visa by the receiving state ${ }^{31}$. For clarification, Article 1 of the Agreement defines a family member as the spouse, son, daughter, parent, legal guardian, sibling,

${ }^{30}$ Citizenship and Immigration Canada, "Final Text of the Safe Third Country Agreement," 5 December 2002, Canada; Retrieved from http://www.cici.gc.ca/english/policy/safe-third.html on 1 February 2006.

${ }^{31}$ Citizenship and Immigration Canada, "Final Text of the Safe Third Country Agreement..." 
grandparent, aunt, uncle, niece, and nephew of a refugee applicant ${ }^{32}$. To be eligible for family reunification exemptions, a host state must have already granted refugee status to a family member or be reviewing the family member's case. Incidentally, since 1980 Canada has accepted more than 4 million immigrants, which greatly increases the potential for family members to reside within the nation ${ }^{33}$. At its most basic, the Agreement exempts refugee claimants who have an established family member with status in the country, who are minors traveling unaccompanied, and who fall under the acceptable visa requirements.

In conjunction with the four main tenets of the Agreement, both Canada and the United States have included several other exemption clauses. For example, the United States has issued an exemption that will allow a refugee claimant to be permitted, as an unreviewable exercise of discretion by the Department of Homeland Security, to pursue a protection claim in the United States because it was determined that it is in the public interest to do so $^{34}$. Further, both countries have agreed that either may review any asylum claim made to it at its discretion, where it determines that it is in the public interest to do so. In addition, Canada has decided to temporarily suspend removals for nationals of Afghanistan, Burundi, the Democratic Republic of Congo, Haiti, Iraq, Liberia, Rwanda, and Zimbabwe, as well as exempting claimants charged with or convicted of an offense punishable by the death penalty ${ }^{35}$. It is the last two exemptions, along with others included in Canadian refugee policy such as the Immigration and Refugee Protection Act, that makes Canada's stance on refugee determination more inviting to refugee claimants seeking protection.

As representatives of two of the most culturally diverse nations in the world, Canada and the United States have been placed into a position where many other states and international organizations view them as countries that should take on the most responsibility of accepting refugee claimants. While this assumption is not necessarily fair, it may be in proportion with the historical, political, and social

\footnotetext{
32 Gallagher, 17.

33 Ibid, 17.

${ }^{34}$ Press Office of the United States Department of Homeland Security, 1.

${ }^{35}$ Harvard Law School, 8.
} 
obligations to which each nation has been linked. Even though both Canada and the United States are party to the 1951 Convention and the 1967 Protocol, it is difficult to ensure that each party complies with their responsibilities and duties concerning refugee protection. Refugee law is implemented differently from any other international human rights law; there is no international tribunal that exists to adjudicate claims that refugees' rights under the 1951 Convention and the 1967 Protocol have been violated ${ }^{36}$. This is not to say that the Canadian and American governments are free to do as they will with refugee policy, thus barring every refugee claimant from finding protection. Neither nation seeks to bar every refugee claimant. Only those who pose a potential threat to society or those who are attempting to enter North America under false pretenses are barred. Rather, it means that the needed international measures to ensure that each party is upholding their obligations does not exist, thus leaving room for interpretation and ambiguity in refugee policy decision-making. Determining responsibility is difficult, and as analysis of the Safe Third Country Agreement will show, both nations have worked to share responsibility despite criticisms declaring that irresponsibility exists.

The fundamental premise of international refugee protection and indeed any organized humanitarian intervention, is that the sovereign state is unable or unwilling to offer effective protection to those individuals whom it is charged by international law to protect from harm. In its myriad forms, international protection of refugees is a temporary surrogacy until effective national protection can be restored. Any sensible analysis of that duty and the kinds of harm which the state is charged to protect people in lead inevitably to human rights standards ${ }^{37}$.

In reality, primary responsibility for each person within a territory or state belongs to the sovereign government of that state. Unfortunately, once the government becomes unwilling or unable to take care of their citizens, the question of responsibility is then shifted on to the international community. Many states and citizens view refugee protection as the responsibility of the United Nations High Commission for Refugees. Incidentally, the role of the UNHCR is to provide protection or assistance to refugees (before and after official recognition), while encouraging some states to participate in determination of refugee status, providing assistance to internally displaced persons, and advising states

\footnotetext{
${ }^{36}$ Fitzpatrick, 4.

${ }^{37}$ Richard Towle, "Human Rights Standards: A Paradigm for Refugee Protection?" in Human Rights and Forced Displacement, eds. Anne F. Bayefsky and Joan Fitzpatrick (The Hague: Martinus Nijhoff Publishers, 2000): 27.
} 
on Convention and Protocol obligations, as well as criticizing state obligation violations ${ }^{38}$. Even though the UNHCR provides all of these services, it is not enough to create a viable and long-term solution to the problem. The political, legal, institutional, and conceptual frameworks that the international community uses to address refugee issues can be viewed as inadequate in the context of contemporary conflict and international relations ${ }^{39}$. While this is not the place to discuss the roles of prolonged famine, civil war, or developed versus developing world discourse, it is important to remember that Canada and the United States do possess the means to provide short-term and some long-term solutions to the international refugee crisis.

While the Safe Third Country Agreement may seem to be a tool used to keep as many refugee claimants as possible from entering North America, it can and should also be viewed as a tool of state security and management that government uses to protect itself and its citizens. Some politicians and governing states view refugee claimants in negative terms, associating them as threats to social cohesion, employment, or even as threats of insurgency and terrorism ${ }^{40}$. Such views have lead to governments taking stronger stances on border control and refugee policies. It is understood by Convention signatories that they are not required to offer permanent asylum to all refugee claimants, which may explain why some states implement stricter legislation. In light of this, such a provision has led states such as Canada and the United States to grant temporary protection and encourage voluntary repatriation when a second or third state has been judged a safe harbour ${ }^{41}$. This appears to be the ideology that Canada and the United States used when forming and implementing the Safe Third Country Agreement. Even though both states, although more the United States, have increasingly viewed refugees and immigrants under a security lens, they have attempted to accord refugee claimants opportunities to seek refuge in North America under the Safe Third Country Agreement.

\footnotetext{
${ }^{38}$ Fitzpatrick, 4.

39 Ibid, 5.

40 Newman, 6-7.

${ }^{41}$ Whittaker, 4.
} 
Though the Safe Third Country Agreement initially makes seeking refugee protection in North America seem difficult to some, it is important to note that over the past few years Canada has drawn thousands of potential refugee claimants. Canada is a preferred destination country for refugee claimants, and in the three-year period between 2000 and 2002, the nation was fifth among developed countries in absolute numbers with 120,102 refugee claimants seeking status. Until the advent of the Safe Third Country Agreement, Canada considered applications from the majority of claimants it received ${ }^{42}$. In fact, it can be argued that Canada possesses one of the most humanitarian refugee determination systems in the world, thus contradicting arguments that Canada wants to keep all refugee claimants from entering the country. There are many pull-factors drawing refugee claimants to Canada such as the ability to work, the existence of family connections, the liberalness of Canada's policies and political values, and the relative ease with which the nation can be reached if one has the means to do $\mathrm{so}^{43}$. Many potential refugee claimants see Canada as a nation that offers safety and a chance to begin a new life with benefits that may not have been available in their home countries.

There are many benefits to Canadian refugee policy, even with the implementation of the Safe Third Country Agreement in place. For example, even with the restrictions of the Safe Third Country Agreement, Canadian refugee policy still assumes the responsibility for protection that is another country's. In some instances, Canada assumes discretionary costs of claimant processing that have required trade-offs with other government expenditure programs ${ }^{44}$. Perhaps most importantly, the government of Canada's interpretations of what constitutes a Convention refugee typically extends beyond international norms by granting Convention status to individuals from countries not generally recognized as producing refugees by any other country ${ }^{45}$. Prior to the implementation of the Agreement, Canada's determination rate during the 1990 's was $61.8 \%$ during a period when no other major destination countries, including the United States, neared 50\%. In 2002, Canada's Convention Refugee

\footnotetext{
${ }^{42}$ Gallagher, 9.

43 Ibid, 5.

4418.

45 Gallagher, 22.
} 
determination rate was the highest among major destination countries, and it was the only developed country to grant protection to more than half of applicants that completed the determination process ${ }^{46}$. Until the implementation of the Safe Third Country Agreement, Canada was a country that offered few barriers to refugee claimants seeking a place of refuge. The advent of a new joint policy with the United States began to change the relatively barrier free refugee policies that Canada implemented in the past at land border ports of entry.

In both developing and developed countries, governments have for some time been constructing legal and physical barriers against the influx of asylum seekers or those displaced by war. 'Safe countries' of origin, whose citizens are in effect precluded from asylum, visa regulations, carrier sanctions, shifting the burden of assessing and processing claims to adjoining territories, physical closing of borders, detention of asylum seekers and withdrawal of welfare support have all been employed to interdict and deter asylum seekers ${ }^{47}$.

The construction of legal and physical barriers to refugee migration is not new, nor is it necessarily wrong. What can be wrong, however, is when a state or states together attempt to seclude themselves and, in effect, shut down avenues of safety to people who are truly in need of protection. This is not to say that Canada or the United States are secluding themselves from all refugee claimants, as there is no solid evidence to support such an insinuation. In fact, it is important to question at this point, why the Agreement was not written so that it would apply to airports, seaports, and other areas of entry where refugee claimants cross. The fact that the Agreement has not been implemented across the board may suggest that both countries are conscious of their international images and obligations, and that they may be using the Agreement as a test to see if such a policy is necessary. While some may argue that the Agreement is a legal barrier to refugee migration, it is important to note that this supposed barrier only affects one source of entry, leaving many other sources still available to potential refugee claimants. Despite the deterring value that the tenets of the Safe Third Country Agreement have, Canada's willingness to use such measures on a regular basis is minimal. The basic framework of Canada's refugee policy and practices does not discourage the choice of Canada as a destination for illegal immigrants, the

\footnotetext{
${ }^{46}$ Gallagher, 22.

${ }^{47}$ Newman, 7.
} 
impact of which will be discussed in future analysis. This allows almost entirely unrestricted access to the regular or full determination process for unlawful arrivals. The use of deterrent measures appears to be based upon the interests of a state at the time of policy implementation and by judgment of the external events that have influence on domestic concerns.

The use of such methods is arguably in line with not only the Safe Third Country Agreement, but with other policies and legislative guidelines already in use in both Canada and the United States. The exceptions agreed upon by both nations in the Safe Third Country Agreement are consistent with the patterns and principles of the Immigration Act and with the Immigration and Refugee Protection Act. For example, Section 46.01 (1) of the Immigration Act states that a person who claims to be a Convention refugee is not eligible to have the claim determined by the Refugee Division if the person came to Canada, directly or indirectly, from a country other than a country of the person's nationality. Where the person has no country of nationality, the country of the person's habitual residence, that is a prescribed country under paragraph 114 (1) (s) will be used to determine eligibility ${ }^{48}$. This principle is in accordance with and similar to the fourth tenet of the Safe Third Country Agreement that insists that a refugee claimant must come directly from their country of nationality or last permanent residence in order to fall under the exceptions. Other exceptions, such as the importance and guidelines outlining family reunification, the best interests of the child, and not returning a refugee claimant to a country where they could possibly face the death penalty, are similar to those outlined in the Immigration and Refugee Protection $\mathrm{Act}^{49}$. The similarities between the two pieces of legislation do not end with those issues. The newly revised Immigration and Refugee Protection Act (IRPA), along with the Safe Third Country Agreement, have both worked to consolidate broader and more sweeping views of refugee policy. In light of ongoing international events, both policies have determined that not all refugee claimants are allowed to make a claim in Canada. IRPA, which was passed in 2001, determined that individuals who fell under specific criteria of the legislation were no longer eligible to have their claims heard by the 48 Abell, 574.

49 Citizenship and Immigration Canada, "Fact Sheet: The Safe Third Country Agreement," 29 December 2004, Canada; Retrieved from http://www.dfait.gc.ca/can-am/main/menu-en.asp on 1 June 2006, 1. 
Immigration and Refugee Board. Such criteria included those under removal orders, those who have already received refugee protection in Canada or in another country to which they can be returned and claimants who have made claims previously that have been rejected by IRB or who have made prior claims that were ineligible, withdrawn, or abandoned. Also, those claimants who have been found inadmissible on grounds of security, violating human or international rights, organized crime or serious criminality, and finally, those who come directly or indirectly from a country designated by the regulations as a safe third country were determined to be ineligible ${ }^{50}$. Judging from the provisions set forth in IRPA, it would appear that the Safe Third Country Agreement has not gone that much farther in proposing stricter measures for refugee claimants. One note of difference must be made: IRPA applies nationwide at all points of entry to all refugee claimants and the STCA only applies at land border crossings. Perhaps it will be seen that the STCA land border restriction has more of an impact on refugee claimants and state security than the broader IRPA policy.

In similar fashion, the United States has connected the Safe Third Country Agreement to immigration and refugee policies prevalent in their nation. For example, the Safe Third Country Agreement states that if a refugee claimant is returned from Canada to the United States, the United States is allowed to return said claimant back to the country from whence they came. It would appear that this contradicts the 1980 Refugee Act in the United States, and contradicts American obligations under said Act and under the incorporation of the Refugee Convention. To be specific:

The incorporation of the Refugee Convention's Protocol in the 1980 Refugee Act bound the US to an obligation not to refoule any person at or within its borders with a legitimate claim to refugee status. While this is not an obligation to grant asylum per se, the difficulties of gaining protection for refugees in other countries makes it a defacto duty ${ }^{51}$.

The operative word in this statement is legitimate. Claimants must have legitimate claims in order to be eligible for refugee status, meaning that the evidence they present to support their claim must be true and their claim must be verifiable. Such terminology would mean that returning a claimant to Canada would

\footnotetext{
${ }^{50}$ Benjamin R. Dolin and Margaret Yong, "Canada's Refugee Protection System," revised October 2002, Government of Canada - Law and Government Division; Retrieved from http://www.parl.gc.ca/information/library/PR8pubs/bp185-e.htm on 28 March 2006.

51 Gibney, 161.
} 
not necessarily constitute a violation of American duties because Canada is thought to be a nation where a claimant's life would not be in danger. In light of this development, it appears that the United States has determined that in order to protect itself from an increase in backlog of refugee claimants and to deter potential claimants, the country must increase effective management of refugee policy.

Three major American refugee and immigration policies, four including the Safe Third Country Agreement, have been designed to combat fraudulent or spurious claims. The first measures began with the Immigration and Naturalization Act (INA). Refugee applicants in the United States must meet the eligibility requirements as set forth in Section 101 (a) (42) of the INA, they must be of special humanitarian concern to the United States, be admissible under the INA, and not be firmly resettled in any foreign country ${ }^{52}$. These clauses are similar to the clauses set forth in the exceptions of the Safe Third Country Agreement that emphasize special interest considerations for specific groups or individual refugee claimants. Also, the 1996 Illegal Immigration Reform and Immigration Responsibility Act, which is a product of the increase in illegal immigration into the United States is important to mention. This particular Act was to reassert political control over asylum, illegal migrants, and migrants convicted at crimes. This Act also brought with it new restrictions that made applying for refugee protection in the United States more difficult. For example, applicants had to lodge their claims within one year of entering the United States. They faced more restrictions on repeat applications. The grounds for rejecting refugee claims were expanded and made mandatory, while increased and expedited removal methods were introduced. There was also an increase in the use of detention and arrest as deterrents ${ }^{53}$. The new restrictions that the 1996 Act brought into American refugee policy can be viewed as a potential foundation for the tenets of the Safe Third Country Agreement. Each of these policies emphasizes better management of refugee claims and the use of deterrents and detention measures, and each provide opportunities for the American government to further control who is allowed to resettle in its territory.

\footnotetext{
52 Kelly Jeffreys, "Refugees and Asylees: 2005 - Annual Flow Report," May 2006, United States Department of Homeland Security - Office of Immigration Statistics Policy Directorate; Retrieved from http://www.useis.gov/graphics/shared/statistics/publications/Refugee Asylee_5.pdf on 20 June 2006, 2.

${ }^{53}$ Gibney, 164.
} 
Finally, the Real ID Act of 11 May 2005 is a more recent example of the lengths to which the United States is willing to go in order to secure not only the state, but to ensure that the government has firm control over who is allowed to enter and exit. While the Real ID Act was implemented after the Safe Third Country Agreement, it effectively enhances and tightens the controls set forth in the joint border agreement in three specific ways. First, the Real ID Act restricts the definition of those who can win protection to those who are able to show not only that they have a well-founded fear of persecution, but also that one of said grounds is a central reason for a claimant's persecution. What this could mean for a refugee claimant is that they may be denied protection because a judge decides that other reasons for persecution dominate. If there is a secondary aspect to a person's claim then the judge may deem that aspect more likely than the primary claim of persecution. Second, the Real ID Act seeks to restrict access to some refugee claimants based on their potential association with terrorist organizations, even if the claimants declare that they were associated only as victims of extortion. The American government is concerned that fraudulent claims will be passed, thus explaining their demand that claimants provide as much information as possible. Proving that someone is a victim of extortion is difficult, due to threats, lack of documentation, and a lack of witnesses. Finally, the Real ID Act has been working to increase the demands on refugee claimants to provide proper documentary or other evidence in order to verify their claims $^{54}$. The Real ID Act has the potential to alert the United States of fraudulent refugee claimants, which is good. Yet, there also exists the possibility for some genuine claimants to slip through the cracks if they are unable to prove extortion or provide all of the necessary evidence. Overall, it would appear that the Safe Third Country Agreement is a culmination of both unilateral and bilateral efforts to secure the borders, maintain state interests, and place security above leniency.

The concepts of state and human security took on entirely new meanings immediately after the terrorist attacks of 11 September 2001 in the United States. From the instant of those attacks until the present, the concepts of migration and security began to be viewed from a state protection perspective. The challenges of refugee migration for societies and governments internationally were exacerbated in the 54 Canadian Council for Refugees, “Closing the Front Door..." 19. 
post-9/11 era. The events of that day and the ensuing 'war on terror' reinforced the connections between human displacement and international security ${ }^{55}$. These events also worked to ensure that both governments would join to put in place a more effective bilateral refugee policy. On 29 October 2001, President Bush ordered his officials to begin harmonizing customs and immigration policies with both bordering states ${ }^{56}$, thus beginning a pattern of American control and influence in North American refugee policies. Both governments agreed upon two areas of cooperation concerning refugee claimants: the creation of a common list of countries exempt from visa requirements and the introduction of a safe third country policy ${ }^{57}$. It can be questioned if the American government was confident in Canada's ability to maintain border security, and run an efficient refugee determination system.

The post-9/11 era ushered in a new phase of refugee determination and ideological reality in North America. A safe third country policy made sense to both countries, as it allowed for the American government to better manage land border ports of entry and slow down the movement of refugee claimants from south to north. To meet the demands, Canada was forced to learn how to respond to the new security environment that was thrust upon it while attempting to ensure that the flow of people and commerce across the common border continued without hindrance ${ }^{58}$. In order to answer the concerns of both nations, the two governments once again came together to establish plans that would work to answer issues regarding border security, the war on terror, the free flow of people across the border, and control of refugee movement. On 12 October 2001, Canada created the Anti-Terrorist Plan that would work to reinforce immigration controls in the political realm, while both countries created the 2001 Joint Statement of Cooperation on Border Security and Regional Migration Issues ${ }^{59}$. Changes in terms of how security began to be viewed related to changes in the way refugee claimants themselves were viewed. The humanitarian aspect of refugee policy, particularly through Canada's new role in the Safe Third

\footnotetext{
55 Newman, 9.

56 Adelman, 7.

57 Ibid, 7.

58 Barry, 209

59 Jacqueline Oxman-Martinez, Jill Hanley and Fanny Gomez, "Canadian Policy on Human Trafficking: A FourYear Analysis,” International Migration, Vol. 43 (4) (2005): 12.
} 
Country Agreement, began to fade in light of the increased need for stronger state security. This change meant that instead of seeing refugee claimants in a humanitarian aspect, they were first viewed through a security lens ${ }^{60}$. While the Safe Third Country Agreement attempts to keep some level of humanitarianism, the primary foundation of the Agreement is state security; keeping those already living in North America safe from those seeking to enter from the outside.

Analyzing the Safe Third Country Agreement from the perspective of a governing body, it is possible to see how and why both Canada and the United States have shifted their philosophical, political, and decision-making responsibilities towards a state security focus. This fuller sense of national security was drawn from the recognition that migration of people across national and international boundaries has the potential to be harmful to the foundations of freedom, security, and confidence that are evoked with North American political discourse. It is interesting to note that this stronger sense of national security brought forth a need for new security strategies that promoted not only security, but also national and bilateral unity, and that reflected the constitutional and democratic values of both Canada and the United States ${ }^{61}$. By working together to create joint measures of deterrence, monitoring, and management of borders, the American and Canadian governments created an effective tool to secure land border points of entry. Some of the aspects of the Agreement and the methods used to implement the tenets of the Agreement leave the researcher wondering how it will be possible for Canada and the United States to meet the demands of social and humanitarian interests that have risen as a result of the implementation of the Safe Third Country Agreement.

States party to safe third country policies often view such legislation as necessary in the protection of territorial boundaries and in the protection of citizens contained within those areas. However, there are those who would argue that such policies lead to the violation of a refugee claimant's human rights. The Canadian government stated that on the policy level, the Canadian and American approaches are substantively similar. Non-governmental organizations, such as the Canadian Council for

${ }^{60}$ Oxman-Martinez, Hanley, and Gomez, 13.

${ }^{61}$ Donald Kerwin, "The Use and Misuse of 'National Security' Rationale in Crafting U.S. Refugee and Immigration Policies," The Author (2006): 751. 
Refugees (CCR), would argue that such a statement assumes there is a uniform approach to decision making and that it ignores the impact of procedural bars, limited access to legal representation, and detention policies of asylum seekers employed by the United States ${ }^{62}$. At this time, it is important to make mention of the fact that organizations such as the CCR and even CIC have the potential to be bias in their viewpoints, as each wants to portray their own vested interests as what should be taking place in the refugee determination system. Therefore, one must be critical of the viewpoints and statistics mentioned in order to address questionable claims and samplings. In addition. it is important to note that although the Agreement has the potential to exclude some claimants, that the proportion of claimants allowed to file a claim has not changed substantially. In the past 20 years alone, Canada has received almost 600,000 people attempting to make refugee claims. In that same period, more than 500, 000 refugee claimants and people in similar situations have been granted Permanent Resident Status ${ }^{63}$. It is safe to state that Canada's allowance of such large numbers of migrants to enter the nation has been generous and humanitarian. There are those who advocate tighter border controls and refugee determination processes, arguing that Canada is too liberal, and entertains high rates of entirely fraudulent claims. Yet, with the advent of a safe third country policy in North America, both of these views may be called into question. With the implementation of the Safe Third Country Agreement came several side affects. For example, several organizations have argued that there has been a relative decline in the number of refugee claimants crossing at land border ports of entry from 2005 until now. Unfortunately, the number of those needing protection across the globe has not declined, nor has the need for protection. According to the UNHCR, the number of people of concern to the organization is approximately 17.1 million, with 9.7 million of these being classified as refugees ${ }^{64}$. Such numbers explain the continuance of migration towards North America, as both countries stand for the very essence of freedom, protection, and opportunity. Since the Agreement was implemented, there has been a $40 \%$ drop in the number of refugee

\footnotetext{
62 Canadian Council for Refugees, “Closing the Front Door,", 15.

63 Gallagher, 5.

${ }^{64}$ Whittaker, 13-14.
} 
protection claims made at Canada-USA land border points of entry from 29 December 2004 to 30 March 2005. It is important to remember that this sampling, as well as the implementation of the Safe Third Country Agreement, came during the winter months. It is possible that the Safe Third Country Agreement may have influenced the decline, but it is also likely that factors such as the weather influenced the number of people presenting themselves at the border during that period. Specifically, Citizenship and Immigration Canada (CIC) reported that the number of refugee claims received in 2005 was lower than in 2004. There were 19,735 claims made in 2005 compared to 25, 521 in 2004. According to $\mathrm{CIC}$, the largest part of this decline resulted from fewer claims being presented at land border ports of entry, where the Agreement applies. There were 4, 033 claims made in 2005 compared to 8, 896 claims made in $2004^{65}$. The staff attorney at Casa Vive (a refugee shelter) in Buffalo, New York claims that the Agreement severely restricts the time and place where a refugee claimant can apply, thus partially explaining why there may have been such a decline between 2004 and $2005^{66}$. While some may say that such a claim is arguable, these statistics can represent a significant decrease from the number of claimants who sought refugee status in Canada during the same period the previous year.

Decreases in claims are not restricted to land border ports of entry alone; there has been a $23 \%$ decrease in refugee claims made at other points of entry in Canada such as airports, marine ports, and inland offices - those areas not covered by the Agreement ${ }^{67}$. There has been a decline in immigration nationally and changes in the number of claims from one year to the next are not uncommon. An even larger decline in the overall number of claims took place between 2003 and 2004, when claims fell from 31, 893 to 25, 251. A significant part of this is attributed to claims made at the Canada-US border, before the Agreement was implemented, where claims declined from 10, 940 in 2003 to 8, 896 in 2004. Such

\footnotetext{
${ }^{65}$ Bruce Scoffield, Director, Operational Coordination in the International Region, former Director, Policy Development and International Protection in the Refugees Branch, Interview by Author, email interview. 5 September 2006.

${ }^{66}$ Maria R. Rosciglione, Staff Attorney Casa Vive Buffalo, New York, Interview by Author, email interview, 24 July 2006.

${ }^{67}$ Citizenship and Immigration Canada, "First Statistics Under Canada-USA Safe Third Country Agreement Show Decline in Refugee Claimants," 13 July 2005 [press release]; Retrieved from http://www.cic.gc.ca/english/policy/safe-third-stats.html on 6 June 2006, 1.
} 
declines are not restricted to Canada alone. According to the UNHCR, the number of refugee claims received in 2005 was in many developed countries at the lowest levels seen in many years. The UNHCR states that applications for asylum in 50 industrialized countries have declined by $49 \%$ between 2001 and 2005. During this same period, the combined numbers for Canada and the U.S. show a $54 \%$ decline ${ }^{68}$. This suggests that there may be other factors influencing such a decline. Some possibilities include the tightening of borders and exit controls in source countries, heavier penalties for airlines carrying undocumented passengers, and the creation of stability or peace in some source countries. Similarly, there have been changes in the number of people coming from Chine, India and other source countries, which in the past produced large numbers of refugee claimants. Today, changes in the economic, political, and even social stability of these areas have decreased the need for people from those areas to seek refugee protection in other nations. It is possible to argue that the Safe Third Country Agreement is one factor among many that has produced a decline in the number of refugee claimants coming to Canada-US borders.

When Canada and the United States agreed to the ratification and implementation of the Safe Third Country Agreement, both governments deemed the other as safe countries for refugees. In light of this, it is interesting to note that more refugees come to Canada through the United States per year than go through Canada to reach the United States. Between 1990 and 2004, an average of 8750 claimants per year applied in Canada at a US-Canada border for refugee status, while during the same time period, the American government cited only 200 individuals as the approximate annual number of claims made in the United States by person entering from Canada ${ }^{69}$. These statistics reveal that there is a more significant impact on Canada from known South-North migration claims than there is on the United States because of North-South movement. However, these statistics may not address the instances of illegal crossings that occur. In both Canada and the United States, the impact on the number of claimants allowed to make claims has decreased in the months following the implementation of the Safe Third Country Agreement.

${ }^{68}$ Scoffield and UNHCR Press Release, "Number of Asylum Seekers Halved Since 2001 says UNHCR," Geneva, 17 March 2006.

${ }^{69}$ Canadian Council for Refugees, "Closing the Front Door," 2. 
In the USA, the total number of persons granted asylum decreased from 27, 169 in 2004 to 25, 257 in $2005^{70}$. Similarly, over the past four years, Canada has seen a steady decrease in the number of claims from a high of 44, 714 in 2001 to a low of 25,521 in $2004^{71}$. While the declines may have come after several years of decrease due to the influence of previous legislation, the number of refugee claims made in Canada at land borders has been halved since 2004 when the Agreement was implemented. The first eleven months of 2005 produced land border claims of only $20 \%$ of all claims in comparison to the two thirds of claims made inland. Comparing 2005 to the period 1989 to 2004, Canada has only received approximately two thirds of the average annual claims and fewer than half the average at land borders ${ }^{72}$. Canadian resources are also heavily used, thus heightening the impact of refugee claimants on Canadian society. It can be contended that more refugee claimants choose Canada as a destination country for its more lenient determination system, access to better social benefits, and the ability to work while not being a permanent resident. The Safe Third Country Agreement has highlighted the decline in numbers in part because of its bilateral nature, the significance of its implementation after 11 September 2001, and due to the interest it drew from media, government, and social sources.

One of the potential problems that refugee advocates cited as an unintended consequence of the Safe Third Country Agreement was an increase in illegal immigration. Illegal immigration has been a concern for both Canada and the United States, primarily because of the large shared border between the two countries and due to the American-Mexico border. Those who tend to enter the country illegally are those who may not qualify under the Safe Third Country Agreements' tenets, and are primarily economic migrants who do not have the grounds to claim traditional refugee status ${ }^{73}$. Non-governmental organizations, refugee advocates, and refugee service providers who work directly with those seeking refugee status tend to disagree with government officials who do not believe that illegal immigration will

70 Jeffreys, 5.

71 Canadian Council for Refugee, "Closing the Front Door..." 3.

72 Canadian Council for Refugee, "Closing the Front Door..." 4.

73 Jeremy Harding, The Uninvited: Refugees at the Rich Man's Gate, (London: Profile Book Ltd and London Review of Books, 2000): 6. 
increase due to the implementation of the Safe Third Country Agreement. The Canadian Broadcasting Corporation reported on 15 May 2006 that refugees applying for status with relatives who entered Canada without authorization contacted several non-governmental organizations for guidance as to their eligibility under the new legislation. The same report stated that Canada's refugee agreement with the United States was forcing people to try to enter Canada illegally, creating a human smuggling problem ${ }^{74}$. $\mathrm{CIC}$ contends that there is no evidence to support the notion that the Agreement has or will promote irregular border crossings. The organization and its representatives have argued that the Agreement has served to encourage persons wishing to make a refugee claim in Canada to avoid presenting themselves at the Canada-US border. They would argue that this has resulted in an increase in the number of refugee claims made at immigration offices outside of Canada. Representatives at CIC have stated that reports from various Canadian and U.S. law enforcement agencies have indicated that apprehensions of irregular migrants known to have attempted to cross the international border declined in 2005 from the previous year $^{75}$. Such information and statements contradict what employees of shelters and other nongovernmental organizations along several border crossings have noted since the implementation of the Agreement. They have noted an increase in the number of attempts to cross the Canada-USA border by irregular methods since the Safe Third Country Agreement went into force in December $2004^{76}$. It may be difficult to trace all forms of illegal immigration and difficult to trace instances of such movements, as a direct result of the Safe Third Country Agreement, but it is plausible to believe that such actions may occur.

Some critics of the Agreement have argued that Colombian refugee claimants crossing at CanadaUS land borders are facing more difficulties because of the new law. There are several examples in which the implementation of the Safe Third Country Agreement has affected the lives of specific groups or individuals. In this instance, Colombian refugee claimants will be discussed. There has been an ongoing

${ }^{74}$ Canadian Broadcasting Corporation, "More Refugees Sneaking into Canada - Study," 15 May 2006, [online news]; Retrieved from http://www.cbc.ca/story/canada/national/2006/05/15/refugees-study-illegal.html on 1 June 2006.

75 Scoffield.

${ }^{76}$ Lynn Hannigan, Director - Casa El Norte (refugee shelter) Fort Erie, Ontario. Interview by Author, 4 July 2006. 
civil war in Colombia, characterized by widespread violations of human rights and international humanitarian law. Left wing guerilla and right wing militia groups carrying out massacres, kidnappings, and torture of civilians have caused the upheaval of many Colombian citizens, not to mention the participation of government troops, drug lords and other criminal syndicates. In 2003 alone, some 250, 000 people were displaced and many of those came to Canada and the United States via land routes ${ }^{77}$. The movement of people out of Colombia has not stopped, and the risks they face when coming across land borders in North America has increased. Such movements of people out of Colombia have also lead to the increased probability that among those so-called Colombian refugee claimants are nationals of other countries posing as Colombians, and those who have been refused due to criminality, making false claims, and other reasons. This makes determining a genuine claimant very difficult for immigration officers at the border, thus creating a need for better border management and a more effective refugee determination system. The Agreement, as in many other situations, forces many Colombians who pass through the US on their way to Canada to make claims in the United States where there is a reduced likelihood of making a successful claim. In the United States, the practice withholding protection from individuals who are thought to have provided material support to terrorist organizations is routine. Such a stipulation hinders Colombian claimants, who may have been forced to pay ransoms or war taxes to paramilitary or guerilla groups from securing fundamental refugee protection in the United States. One study, conducted by the Harvard Law School, estimates that there are approximately 150, 000 Colombians without legal status in the United States due to both the Safe Third Country Agreement and the lack of opportunity they have to file an acceptable claim ${ }^{78}$. As many Colombian claimants try to make their way to Canada, they are forced to abide by the Safe Third Country Agreement when they reach a Canada-USA land border and file a claim in the United States or risk attempting to enter Canada under other methods.

\footnotetext{
${ }^{77}$ Harvard Law School, 17.

${ }^{78}$ Harvard Law School, 17-18.
} 
The impact of the Agreement on Colombian refugee claimants does not end in the United States. Colombians trying to enter Canada have also been affected. In 2004, Colombia represented the top country of origin, with $14 \%$ of the total claimants in Canada being from that country. Ninety-seven percent of Colombians made their claims at land border, while only $35 \%$ of all other claimants made their claims there. However, since the implementation of the Agreement, non-governmental organizations claim that there is less than one quarter as many claims by Colombians at land borders as in $2004^{79}$. Throughout 2005 , only $30 \%$ of the numbers of claims made by Colombians were filed in comparison to 2004. The Canadian Council for Refugees claims that that $30 \%$ represented a shortfall of over 2500 Colombians who would have pursued refugee status in Canada if the Agreement had not been in place ${ }^{80}$. It is necessary to question whether all of the claims that were lost would have been genuine, accepted, or even considered under the Agreement if they had been made. In addition, there may have been other extenuating circumstances besides the Agreement that kept these claimants from applying in Canada not mentioned by the CCR or by other organizations accumulating such statistics. It is difficult for many Colombian refugees to come to Canada without passing through the United States because there are not many direct flights from Colombia to Canada, and if they take a land route, they must pass through the United States, thus designating America as their first country of safety. In addition, the family exception in the Agreement excludes many Colombians from being able to apply in Canada because they do not have family in the nation ${ }^{81}$. Some organizations, such as the Canadian Council for Refugees, would suggest that the Agreement is not only affecting where a Colombian claimant must make a claim, but also the ways in which they will change their plans in order to make claims in Canada. Critics would argue that if a claimant is genuine, then they should have no problems making a claim in either Canada or the United States, thus precluding them from making dangerous plans to enter Canada in other ways.

\footnotetext{
79 Canadian Council for Refugees, “Closing the Front Door," 8.

80 Ibid, 8.

${ }^{81}$ Canadian Council for Refugees, "Closing the Front Door..." 8.
} 
Canada, before the implementation of the Agreement, presumably represented a safer haven for Colombian refugee claimants and offered a better opportunity for claims to be heard by immigration officials. When comparing the acceptance rates between Canada and the United States, it is possible to gain an understanding of why Colombian claimants would want to pursue their claims in Canada. In $2004,81 \%$ of Colombian claims made in Canada were accepted, while in comparison, only $45 \%$ of affirmative Colombian claims were accepted in the United States and only $22 \%$ were accepted when appearing before an immigration judge ${ }^{82}$. Those statistics alone are arguably enough to draw Colombian claimants to the Canada border in hopes of filing a claim. Further research found that in the first year of the Agreement, approximately 922 Colombians who may have received protection in Canada instead faced detention, removal to Colombia, or lives without status in the United States because they did not qualify for status under the Agreement ${ }^{83}$. In order to face removal, they would also have had to be ineligible for status under the American refugee determination system. A safe third country policy is supposed to work to better manage borders, share responsibility between two or more countries, and help with the orderly processing of claims. The Agreement has instead caused uncertainty and instability for some refugee claimants, forced them to choose other methods of entry into Canada, or risk having their claims denied by the American refugee determination system. Theoretically, the Agreement protected Canada from dealing with fraudulent claims stemming from migration out of Colombia.

Recently, a Colombian refugee claimant in the United States petitioned the Canadian government to allow him to file a status claim in Canada. The claimant, who came to the United States with his wife, had been rejected in the United States because he missed the one-year filing deadline and now faces deportation. He is the only refugee claimant to have filed a constitutional challenge against the Agreement since its implementation ${ }^{84}$. The day after the media reported the initial story, the Federal Court of Canada dismissed the claimant's bid to come to Canada to enter a challenge against the Safe

\footnotetext{
82 Canadian Council for Refugees, "Closing the Front Door..." 9.

83 Canadian Council for Refugees, "Closing the Front Door" 9.

${ }^{84}$ Nicholas Keung, Refugee Seeks Right to Stay in Canada. The Toronto Star. (30 August 2006): B1 and B5.
} 
Third Country Agreement. The Federal Court dismissed the claim because the refugee claimant could not convince the court of the irreparable harm he would face if he were to be denied entry to Canada to challenge the Agreement ${ }^{85}$. If the challenge had been approved and the claimant had been allowed to enter Canada, the Agreement would have been in jeopardy of losing credibility, not to mention the possibility that hundreds of failed claimants from both Canada and the United States would follow suit and file similar challenges in order to have the opportunity to gain refugee status. This situation does highlight the potential risks that refugee claimants are facing if they do challenge the Agreement, while at the same time revealing how persistent both the Canadian courts and the Canadian government are in wanting to ensure that the Agreement is upheld.

Finally, there is potential for the risk of direct backs to increase as a result of the Safe Third Country Agreement. Direct backs and detention are important side affects of the Agreement to mention, as they constitute a potential threat to the people who attempt to cross the Canada-USA border. By coming to the border to make a claim, they risk exposing themselves to detention if sent back to the United States or even deportation if their claims fail in the United States ${ }^{86}$. Being directed back does not mean that a person is immediately returned to their country of origin. Rather, it means that they will be directed back to the country of first landing, in this case either Canada or the United States, until their claims can be properly assessed. Theoretically, a person directed back is allowed to come forward to make their claim at another time. Typically, those who do not meet one of the exceptions under the Agreement and who make claims at the border and face detention or deportation are those who have had no contact with any refugee related non-governmental organizations. Those who are able to contact such organizations or even immigration lawyers are able to find out information as to their eligibility under the joint Agreement. Between, January and November 2005, 281 claimants were denied eligibility based on the Safe Third Country Agreement, thus leaving them vulnerable to detention, direct back, or at most,

${ }^{85}$ Nicholas Keung, Man Loses His Bid to Come to Canada, The Toronto Star (31 August 2006); Retrieved from http://www.thestar.com/NASApp/cs/ContentServer?pagename=thestar/Layout/Article Type1 \&c=Article\&pubid=96 $8163964505 \& \mathrm{cid}=1156974612466 \& \mathrm{col}=968705899037 \& \mathrm{call}$ page $=T S$ News\&call pageid $=968332188492 \& \mathrm{call}$ pagepath=News/News on 1 September 2006.

${ }^{86}$ Canadian Council for Refugees, "Closing the Front Door..." 10. 
deportation ${ }^{87}$. Some would argue that it is necessary to detain claimants who have no identification or who are ineligible in order to ensure that a potentially fraudulent claimant is not allowed into the country.

Directly after the implementation of the Agreement on 29 December 2004, the utilization of the direct back method and even the use of detention were at their highest. Between 1 January 2005 and 31 May 2005, forty-seven claimants were directed back and twelve failed to re-appear for their scheduled interviews $^{88}$. Some critics would argue that the direct back of 47 claimants is quite low and not highly significant, but others would argue that even such a small number of people represent potential risks to claims who may have had legitimate claims. However, the statistics do not show the extenuating circumstances that may have been involved in those direct backs. Direct backs were a method used prior to the implementation of the Agreement in 2004 as a result of the 1976 Immigration Act. Directing persons back to the United States was permissible under sections 20 (2) and 23 (4). These sections allowed immigration officers to return persons to the United States if the officer was of the opinion that it would be contrary to the Act or regulations to grant that person admission to Canada. A person could also be directed back if a senior immigration officer were required to cause an inquiry to be held with respect to said person and an adjudicator was not available until a later date to preside at the hearing. When an adjudicator was available to preside at the hearing, the claimant would then be allowed to return to make their claim ${ }^{89}$. Prior to and after the implementation of the Safe Third Country Agreement, the direct back method was most notably significant at land border crossings at the Fort Erie/Buffalo border, the Lacolle border crossing, and at the Windsor/Detroit crossing after implementation.

New guidelines implemented on 27 January 2003 for the use of direct backs were much different in policy then what border officials had been practicing. The policy stated that direct backs were to be special measures not to be used indiscriminately but selectively and responsibly, preferably as tools to

87 Canadian Council for Refugees, “Closing the Front Door...", 12.

88 Canadian Council for Refugee, "Closing the Front Door..." 23.

89 Canada. "Immigration Act, 1976." Supply and Services Canada, 1984, 1v. 15-16. 
manage unusual flows or unavailability of critical resources ${ }^{90}$. In the few days prior to implementation, Canadian immigration officials at the Fort Erie-Buffalo border directed refugee claimants back to Buffalo, giving them appointments for claiming status, while at the same time allowing claims to be heard at Vive la Casa refugee shelter in order to stem the flow at the Peace Bridge ${ }^{91}$. At the Fort Erie, Ontario Buffalo, New York border, direct backs were a common occurrence, with some of those directed back across the border to New York being placed in detention at the Batavia Federal Detention Facility. The Canadian Council for Refugees and Vive la Casa both noted that the number of claimants being processed each day was smaller than the number of claimants coming to the border to claim refugee status, thus creating a backlog ${ }^{92}$. At the Lacolle border crossing in Quebec, Citizenship and Immigration Canada had a policy to direct back all claimants at the border, except unaccompanied minors. Such direct backs were apparently the standard method of operating procedure at Lacolle, despite the fact that the methods used runs counter to instructions for front-end processing of refugee claimants. This may be due in part to the geographical location of Lacolle in rural Quebec, and due to a lack of proper facilities pertaining to refugee housing. Similar methods have been used at the Windsor, Ontario-Detroit, Michigan border crossing, but to a lesser extent ${ }^{93}$. During the summer of 2006, Citizenship and Immigration Canada began to reduce and ultimately end the use of direct backs at certain border crossings, such as in the Niagara Region. This change was to take affect in August of 2006, and raises many questions as to what the new procedures for returning failed claimants back to the United States will be $\mathrm{e}^{94}$. The direct back procedure can be an effective border management tool, in that it allows border officials to more efficiently and -effectively process refugee claimants. However, direct backs can and do have negative effects: higher

90 Canadian Council for Refugees, "Impacts of Directing Refugee Claimants Back to the United States," 2006 OCASI Professional Development Conference; Retrieved from http://www.ocasi.org/index.php?qid=668\&catid=86 on 26 June 2006

91 Canadian Council for Refugees, "Closing the Front Door," 27.

92 Canadian Council for Refugees, "Impacts of Directing Refugee Claimants..." 1.

93 Ibid, 1.

94 Hannigan. 
risk for detention, probability that refugee claimants will not return for their appointments due to detention or other reasons, and the risk of living without status in Canada or the United States.

To put the impacts of the Safe Third Country Agreement on refugee claimants in perspective, it is necessary to note that the above mentioned problems can be classified in part as potential problems due to the lack of available evidence to suggest a major pattern of change. Both Canada and the United States need to be more aware of the risks that the Agreement poses as the years of its usage continue. Though the current patterns show minimal changes in refugee claimant processing, it is possible that in five to ten years the Agreement will have changed how refugee claimants access the refugee determination system in North America and change how states view refugees themselves.

To view this from a Canadian perspective, one must think of the ways in which Canadians and the Canadian government views their responsibilities towards potential refugee claimants. At stake is Canada's self-image and rational for implementing joint agreements such as the Safe Third Country Agreement. From a domestic perspective, it is important for both citizens and government to understand how the Safe Third Country Agreement works within the national legislation. Section 7 of the Canadian Charter of Rights and Freedoms entrenches three fundamental rights that are available to all who come to Canada: the right to life, the right to liberty, and the right to security of person ${ }^{95}$. It can be argued that the Safe Third Country Agreement does ensure these rights to a refugee claimant, but only if they are able to meet the requirements of the policy. Domestically, the Canadian refugee protection system must balance state interests, the fundamental rights and freedoms available to all, its own policies and legislation, as well as the interests and rights of those applying for refugee status. On a larger scale, the refugee protection system must balance the following in order to be effective: the essence of UN Conventions and Protocols, Canada's obligation under the Convention Against Torture and Other Cruel, Inhuman or Degrading Treatment or Punishment and the Canadian Charter of Rights and Freedoms. It must also ensure that laws regarding the spontaneous arrival of refugee claimants are stringent enough to counteract

${ }^{95}$ Abell, 575, 
the perception that Canada does not have control over her territorial borders ${ }^{96}$. The Canadian government also needs to be continuously aware of the risk factors involved in implementing such a policy. Thorough analysis of the statutory factors that designate a country as safe is needed to ensure that compliance with international and domestic legal requirements occurs. A firmly established review process should also be implemented. In addition, proper training of immigration officials and others, as well as the need to ensure that exceptions properly address circumstances where a specific country should take responsibility for assessing a refugee claimant are necessary ${ }^{97}$. Finally, as has been affirmed by several sources, it is important that availability of information regarding the Safe Third Country Agreement is increased in order to help potential refugee claimants make informed choices as to which country they should apply to. As has been seen throughout the above, there are conflicting views as to whether the Safe Third Country Agreement has in fact balanced all of these issues into one manageable and effective policy.

It may be possible to clarify these conflicting views by mentioning the views of the 1951 Convention Relating to the Status of Refugees. The Convention requires that a refugee claimant must arrive directly from where their life or freedom has been threatened before Article 31 (1) of the Convention can apply. Article 31 (1) of the Convention states that Contracting States shall not impose penalties on refugee claimants if they come directly from the nation that is threatening them, or if they present themselves immediately and can show good cause for their illegal entry or presence. Similarly, Conclusion 15 (XXX) (1979), paragraph (h) (vi) of the Convention claims that Agreements providing for the return by States of persons who have entered their territory from another contracting State in an unlawful manner is applicable if the States show proper consideration of a claimant's situation. This is similar to Conclusion No. 58 (XL) (1989) on Irregular Movements, paragraphs (f) and (g), which together accept that a refugee/asylum-seeker may be returned to the country of first asylum if the person can enter and remain there. This concept also applies if a person is protected in that country against refoulement, is treated in accordance with basic human standards, is not subject to persecution or threats to safety and

\footnotetext{
96 Dolin and Young, 1.

97 Scoffield.
} 
liberty, and has access to a durable solution ${ }^{98}$. While not all of those involved in the refugee sector would agree that the Convention truly protects or provides a legal basis for a safe third country policy, it is clear that the Convention does indeed provide at least some guidance on the issue. It is clear from the Convention that a refugee claimant does have a right to apply in a safe country, but that they must do so in the first territory they arrive in that is deemed by the UNHCR to be safe.

For the most part, from a policy perspective, the Agreement has successfully managed to counteract both American and Canadian criticisms regarding a Canadian lack of control over borders, and the Agreement has at its most basic met Canada's international obligations. Some doubts exist to the Agreement's ability to properly balance these issues and to its ability to continue Canada's humanitarian approach to the international refugee crisis. There are those who believe that the Agreement has failed with respect to its proposed purpose of enhancing the orderly handlings of refugee claims, strengthening public confidence in the refugee determination system, and reducing the abuse of refugee programs. In theory, the Agreement has been justified as a way to allow for better access to Canada's refugee determination system and as an effective method to ensure that Canada fairly assumes its share of the international responsibility crisis. In practice, the Agreement has done an effective job at presenting itself as a management tool, though there also exists the appearance of a security blanket that works to secure Canada's border from being infiltrated by outsiders. By completing this research on the Safe Third Country Agreement, it is hoped that the observations made will contribute to not only public knowledge, but also to the knowledge of the government. It is important to show the government and societies that, yes, state security is important, but so are those experiencing personal insecurity. Examining cross border relations between Canada and the United States in light of the Agreement will help to reveal how beneficial and harmful bilateral agreements of this nature are. Similarly, examining the impacts of the Agreement on the success and failure of refugee applicants is important because it draws out issues of human security, state obligation to international legislation, and the social consequences of government

\footnotetext{
98 United Nations High Commissioner for Refugees, "Background Note on the Safe Country Concept and Refugee Status - EC/SCP/68," Copyright 2001-2006, UNHCR; Retrieved from http://www.unhcr.org/cgibin/texis/vtx/excom/opendoc.htm?tbl=EXCOM\&page=home\&id=3ae68ccec on 15 September 2006.
} 
policies. Finally, it is important to remind all parties involved that the international refugee crisis is ongoing and no matter the policy, there will always be people knocking at the gates of countries who have peace. 
Appendix A: Literature Review 
As the international refugee crisis continues and spreads across the globe, opportunities for protection in countries outside of one's country of origin appear to be shrinking. Governments and societies in general, are relying policies such as the Safe Third Country Agreement to restrict and regulate who is allowed to enter North America. Instead of focusing on the human and legal rights of refugees, governments are instead focusing on the rights of the state and of those whom the state already protects. In the post-9/11 era, countries around the world have become increasingly concerned with matters of security. The term security encompasses many aspects, depending on which state is concerned, and who or what parties are involved. In this literature review, the term security will encompass human security, national security, international security and other forms of security pursuant to the means of ensuring the right to life, liberty, and security of person ${ }^{99}$. Security is linked to immigration and the migration of refugees because with each person allowed to cross a border in search of safety, the possibility exists for a state to become less secure, thus placing citizens and legal residents at risk.

In order to understand the Safe Third Country Agreement and its impacts on North American relations, as well as the direct and indirect impacts on refugees, it is necessary to conduct a review of some of the available literature. Within the literature reviewed to this point, two major issues arose: human rights and state responsibility, and human security and state security. The research selected for this review is limited in scope to pieces surrounding political aspects of refugee regulations and to pieces discussing the growing relationship between Canada and the United States. It is necessary to note that many of the sources available on the Safe Third Country Agreement have the potential to be biased and do contain the vested interests of an organizations and governments. Studying all of these issues is important because they have resulted from an Agreement developed and implemented under state authority, yet designed in a way that brings cause for concern over the way in which human rights and human security are affected.

In this section, an analysis of several agreements, such as the 1951 Convention on the Status of Refugees, the Canadian Charter of Rights and Freedoms, and the Safe Third Country Agreement will be 
given. These agreements and conventions each discuss the rights of individuals, the responsibilities and rights of state signatories, and the mutual obligations to promote and protect human rights and fundamental freedoms. The purpose of the 1951 Convention Relating to the Status Refugees, also known as the Geneva Convention, was to establish a direct and permanent method of finding a solution to the international refugee crisis after World War Two. First, concerning the definition of a refugee, the Convention clearly establishes that such a person must have a well-founded fear of persecution due to reasons of race, religion, nationality, membership of a particular social group or political opinion, and be unable or unwilling to return to their country of origin ${ }^{100}$. Further, the Convention establishes that a person granted refugee status has duties to maintain public order and to conform to a receiving country's laws and regulations. The Convention also determined that the state signatories are obligated to apply the provisions of the Convention to those deemed refugees without discrimination as to religion, race, or country of origin and to grant accepted refugees the rights of the host country ${ }^{101}$. However, the current definition fails to recognize that some people may have a well-founded fear of economic, environmental, or authoritative persecution. In the context of the subjects to be studied, the 1951 Convention is important because it not only establishes what individuals or groups may be protected under international law, but also the duties, rights, and obligations of the state in providing safe havens for such groups.

In comparison, the 1982 Canadian Charter of Rights and Freedoms, and the 2002 Safe Third Country Agreement tend to focus more specifically on the rights and securities of citizens in the host country, as well as security concerns of the state. For example, under the Canadian Charter of Rights and Freedoms, the rights of a citizen or permanent resident of Canada include democratic, mobility, legal, equality, and language rights ${ }^{102}$. While each of these articles is clear about who is granted such rights, ambiguity exists under the section guaranteeing fundamental freedoms. This particular section alludes that everyone is entitled to such freedoms as freedom of religion, conscience, thought, beliefs, opinions,

${ }^{100}$ United Nations High Commissioner for Refugees, "1951 Convention Relating to the Status of Refugees," 28 July 1951, Retrieved from http://www.unhchr.ch/html/menu3/b/o_ c ref.htm on 1 February 2006, 1.

${ }_{101}$ UNHCR, 2-3.

102 Department of Justice Canada, "Canadian Charter of Rights and Freedoms." Government of Canada, 1982. Retrieved from http://laws.justice.gc.ca/en/charter/ on 1 February 2006. 
expression, peaceful assembly, and association ${ }^{103}$. Within the context of the statement made at the beginning of this paper, the Charter rightfully takes into consideration the rights and concerns of the citizens and permanent residents of the state, as well their security. Similarly, protection and security of the state are two of the driving forces behind the Safe Third Country Agreement between Canada and the United States. Each party wants to establish itself as a safe haven for individuals in need of protection from their countries of origin. At the same time, both Canada and the United States want to be firm in their intention that state security is their primary purpose. Following the attacks in the United States on 11 September 2001, the implementation of the Agreement and its implications became even more important to understand. After reading this Agreement, one can question if there may be a return to isolationism in both countries, and if each country is more concerned with taking care of state security before human security. Included in the preamble of the Agreement is a stipulation that each party has a mutual obligation to promote and protect the human rights and fundamental freedoms of those seeking asylum, as per their international legal obligations under the 1951 Convention and the 1967 Protocol $^{104}$. This Agreement has the potential to establish what role North America will play in addressing the continuing migration of refugees, and under what circumstances state security will usurp human security.

Human security and human rights are linked together, as the definition of each emphasizes freedom from fear, danger and threat. The concept of human security encompasses the protection of people from critical and life-threatening dangers, is human-centered with is principle focus on both individuals and communal groups, and can be security oriented in that the focus is on freedom from danger, threat, and fear ${ }^{105}$. According to an article written by Edward Newman, human security should be included in security discourse, both internationally and domestically. Newman and others argue that contemporary security must focus on the individual or people collectively, and should include issues of

\footnotetext{
103 Ibid.

104 Citizenship and Immigration Canada, "Final Text of the Safe Third Country Agreement..."

105 Newman, 15.
} 
survival, as well as ways to address the root causes of human insecurity ${ }^{106}$. The theme of human security and its link to human rights has become an important issue since the end of World War Two, and most certainly after 11 September 2001. Under the Safe Third Country Agreement, the idea of human security is included, but further research is needed to determine whether it is the human security of citizens or the human security of asylum seekers that is most important.

Also prevalent within the literature written about the Safe Third Country Agreement were concerns about the American refugee determination system and how both the Agreement and the U.S. system may affect refugees forced to make a claim in the United States. Of issue in the American refugee determination system are policies that encourage expedited removals for those without proper documents, and the detention child migrants ${ }^{107}$. Several authors have noted that there is concern over America's refusal to ratify the Convention on the Rights of the Child, which could affect minors attempting to seek asylum in Canada but who are returned to the United States. Children are also not entitled to free representation in deportation hearings because such hearings are considered a civil matter ${ }^{108}$. Also of concern in several documents was the existence of the one-year filing deadline for asylum applicants, which has the potential to prohibit some claimants from acceptance based on failure to fulfill formal requirements. Several studies mentioned that refugee advocates and non-governmental agencies were concerned about the routine use of detention by immigration officials when assessing refugee claimants ${ }^{109}$. Finally, other sources mentioned problems such as lack of available social services and benefits, the inadequate quality of decision-making by immigration judges, and a general lack of information in terms of the requirements of the new Agreement and about the American refugee determination system ${ }^{110}$. In all, it would appear that non-governmental agencies and authors who were discussing the impacts of the Agreement believe that there are problems in the American refugee

\footnotetext{
106 Ibid, 15.

107 Lowry, 35

108 Ibid, 36.

${ }^{109}$ Harvard Law School, 2 and the Canadian Council for Refugees, "Closing the Front Door..." 20.

${ }^{110}$ Canadian Council for Refugees, "Closing the Front Door..." 25.
} 
determination system that could prevent some refugee claimants from receiving a fair chance to file a claim, even if their claims are legitimate. It is important to mention that governments in both countries have attempted to evaluate this list of concerns, and they would argue that neither country presents a threat to the life of any potential refugee claimant.

Finally, the theme of state security seems to be the most prevalent in the articles examined for this review. While the Convention, Charter, and the Agreement each alluded to the importance of state security and responsibilities in their literature, it is in the background and review articles where the issue of state security is thoroughly discussed. In an article written by Joanne van Selm, van Selm asks whether broader conceptions of security, meaning going beyond military and state-centric dimensions, could positively affect refugee protection ${ }^{111}$. The concept of security is ambiguous and is sometimes defined according to what scenario it is being discussed. According to Astri Suhrke, the analytical core of security includes the protection of central values and the basic means of survival. He argues that the ultimate obligation of a government is to ensure the protection of the nation state ${ }^{112}$. Security of the state means defending a territory against, and deterring, anything or anyone deemed an external threat to a nation. It would seem that some of the conclusions written about the Agreement suggest that by implementing this regulation, both Canada and the United States are securing themselves from possible external threats and potentially limiting the opportunities for others to achieve human security.

In sum, the literature available on the Safe Third Country Agreement, human rights, human security, and state security and responsibility, is focused on state-centric dimensions. The human aspect and the sociological impacts of the Agreement and these issues have not been discussed thoroughly in all of the reviewed literature. The notion of a safe third country policy raises several key questions. The first is whether the return of a refugee claimant to a Party that is not itself a signatory of the Refugee Convention is lawful. The second concerns whether it is enough that the destination state does not or will not itself persecute the refugee claimant or engage in refoulement. Finally, it is important to question

\footnotetext{
111 van Selm, 66.

112 Suhrke, 93-94.
} 
whether it is fair for governments to make blanket determinations of safety without fully examining individuals' circumstances ${ }^{113}$. There were a range of issues and theme discussed in several of the articles reviewed, but in maintaining the scope of this review, it was important to limit the discussion to the most prevalent themes that appeared. The movement of people has become an international concern, specifically when discussing the ramifications of refugees and displaced persons. It is in this context that the study of the Safe Third Country Agreement as a North American solution to both state security and human security is important. Analysis of the conventions and agreements relating to refugees has proven that the literature available on issues surrounding refugee resettlement is becoming outdated due to continuous changes in the international community and that it is important to continue to study the effects and impacts of legislation such as the Safe Third Country Agreement.

${ }^{113}$ Hathaway, 327-328. 


\section{Bibliography}

Abell, Nazare Albuquerque. "Safe Country Provisions in Canada and in the European Union: A Critical Assessment.” The International Migration Review, Vol. 31 Issue 3 (Fall 1997): 569-590.

Adelman, Howard. "Refugees and Border Security Post-September 11." Refuge, Vol. 20 No. 4 (August 2002): 5-14.

Barry, Donald. “Managing Canada - US Relations in the Post-9/11 Era: Do We Need a Big Idea?" Policy Papers on the Americas - Centre for Strategic and International Studies. Vol. XIV, Study 11 (November 2003).

Boyd, Monica and Elizabeth M. Greico. "Triumphant Transitions: Socioeconomic Achievements of the Second Generation in Canada." The International Migration Review. Vol. 32, No. 4 (Winter 1998): 853-876.

Canadian Broadcasting Corporation. "Lawmakers Express Worries Over New U.S. Refugee Agreement." 02 December 2002. Canadian Broadcasting Corporation. Retrieved from http://www.cbc.ca/story/canada/national/2002/12/02/safe third021202.html on 1 June 2006.

Canadian Broadcasting Corporation. "More Refugees Sneaking into Canada: Study." 15 May 2006. Canadian Broadcasting Corporation. Retrieved from http://www.cbc.ca/story/canada/national/2006/05/15/refugees-study-illegal.html on 1 June 2006.

Canadian Council for Refugees (CCR). "Closing the Front Door on Refugees: Report on the First Year of . the Safe Third Country Agreement." Canadian Council for Refugees (CCR) December 2005. Montreal, Quebec.

Canadian Council for Refugees (CCR). "Impacts of Directing Refugee Claimants Back to the United States." 2006 OCASI Professional Development Conference. Retrieved from http://www.ocasi.org/index.php?qid=668\& catid=86 on 26 June 2006.

Centre for Research and Information on Canada. "Canada-US Border." Centre for Research and Information on Canada (CRIC). Retrieved from http://www.cric.ca/en_html/guide/border/border.html on 4 September 2006.

Chua, June. "Becoming Canadian." Canadian Broadcasting Corporation, 2002. Retrieved from http://www.cbc.ca/news/becomingcanadian/refugee.html on 2 September 2006.

Citizenship and Immigration Canada. "A Look at Canada: What Does Canadian Citizenship Mean?" Canada. Retrieved from http://www.cic.gc.ca/English/citizen/look/look-02e.html on 2 September 2006.

Citizenship and Immigration Canada. "Fact Sheet: The Safe Third Country Agreement." 29 December 2004. Canada. Retrieved from http://www.dfait.gc.ca/can-am/main/menu-en.asp on 1 June 2006.

Citizenship and Immigration Canada. "Final Text of the Safe Third Country Agreement." Canada. 5 December 2002. Canada. Retrieved from http://www.cic.gc.ca/english/policy/safe-third.html on 1 February 2006. 
Citizenship and Immigration Canada. "First Statistics Under Canada-U.S. Safe Third Country Agreement Show Decline in Refugee Claimants." 13 July 2005. Canada. Retrieved from http://www.cic.gc.ca/english/policy/safe-third-stats.html on 6 June 2006.

Citizenship and Immigration Canada. "Immigration and Refugee Protection Act" (IRPA). 28 June 2002. Canada. Retrieved from http://laws.justice.gc.ca/en/1-2.5/245769.html on 1 June 2006.

Citizenship and Immigration Canada. "Safe Third Country Agreement Comes into Force Today." 29 December 2004. Canada. Retrieved from http://www.cic.gc.ca/english/press/04/0420-pre.html on 6 June 2006.

Department of Justice Canada. “Canadian Charter of Rights and Freedoms.” Canada, 1982. Retrieved from http://laws.justice.gc.ca/en/charter/ on 1 February 2006.

Dolin, Benjamin R. and Margaret Young. “Canada's Refugee Protection System.” Revised October 2002, Government of Canada - Law and Government Division. Retrieved from http://www.parl.gc.ca/information/library/PR8pubs/bp185-e.htm on 28 March 2006.

Dona, Girogia and John W. Berry. "Refugee Acculturation and Re-Acculturation," in Refugees: Perspectives on the Experiences of Forced Migration, ed. Alastair Ager. New York: Pinter, 1999, 169-195.

Fitzpatrick, Joan. "The Human Rights of Refugees, Asylum Seekers, and Internally Displaced Persons: A Basic Introduction," in Human Rights, Protection for Refugees, Asylum Seekers, and Internally Displaced Persons: A Guide to International Mechanisms and Procedures, ed. Joan Fitzpatrick. New York: United Nations University Press, 2003, 1-22.

Gallagher, Stephen. “Canada's Dysfunctional Refugee Determination System: Canadian Asylum Policy from a Comparative Perspective." Vancouver: Fraser Institute, 2003.

Gibney, Matthew. The Ethics and Politics of Asylum: Liberal Democracy and the Response to Refugees. Cambridge: Cambridge University Press, 2004.

Goodwin-Gill, Guy S. and Judith Kumin. "Refugees in Limbo and Canada's International Obligations." Caledon Institute of Social Policy (September 2000): 1-22.

Hannigan, Lynn. Director Casa El Norte Fort Erie, Ontario. Interview by Author, 4 July 2006.

Harvard Law School. "Bordering on Failure: The U.S. - Canada Safe Third Country Agreement Fifteen Months After Implementation." Harvard Law Student Advocates for Human Rights, the International Human Rights Clinic, Human Rights Program, and Harvard Immigration and Refugee Clinical Program. March 2006.

Hathaway, James C. The Rights of Refugees Under International Law. New York: Cambridge University Press, 2005.

Harding, Jeremy. The Uninvited: Refugee's at the Rich Man's Gate. London: Profile Book Ltd and London Review of Books, 2000.

Jeffreys, Kelly. "Refugees and Asylees: 2005 Annual Flow Report.” May 2006 United States Department of Homeland Security - Office of Immigration Statistics Policy Directorate. Retrieved from 
http://www.uscis.gov/graphics/shared/statistics/publications/Refugee Asylee 5.pdf on $20 \mathrm{June}$ 2006.

Kelertas, Daiva. Settlement Worker - Fort Erie Multicultural Centre. Interview by Author, 1 August 2006.

Keung, Nicholas. Man Loses His Bid to Come to Canada. The Toronto Star. 31 August 2006. Retrieved from

http://www.thestar.com/NASApp/cs/ContentServer?pagename=thestar/Layout/Article Type\&cal 1 pageid $=971358637177 \& \mathrm{c}=$ Article\&cid $=1156974612466$ on 1 September 2006.

Keung, Nicholas. Refugee Seeks Right to Stay in Canada. The Toronto Star. 30 August 2006, B1 and B5.

- Kerwin, Donald. "The Use and Misuse of 'National Security' Rationale in Crafting U.S. Refugee and Immigration Policies." The Author (2006): 749-763.

Krauss, Clifford and Robert Pear. Refugees Rush to Canada to Beat an Asylum Deadline. New York Times, 28 December 2004, A9.

, Lowry, Michelle. "Creating Human Insecurity: the National Security Focus in Canada's Immigration System." Refuge (November 2002): 28-39.

Mamann, Guidy. Immigration Lawyer - Mamann and Associates. Interview by Author, 20 July 2006.

Newman, Edward. "Refugees, International Security, and Human Vulnerability: Introduction and Survey," in Refugees and Forced Displacement: International Security, Human Vulnerability, and the State, (eds.) Edward Newman and Joanne van Selm. New York: United Nations University Press, 2003, 3-30.

Nyers, Peter. Rethinking Refugees: Beyond States of Emergency. New York: Routledge, 2006.

Office of the High Commissioner for Human Rights. "Convention Relating to the Status of Refugees." United Nations High Commission for Refugees, July 1951. Retrieved from http://www.unhchr.ch/html/menu3/b/o_c ref.htm on 11 April 2006.

Oxman-Martinez, Jacqueline, Jill Hanley and Fanny Gomez. "Canadian Policy on Human Trafficking: A Four-Year Analysis.” International Migration, Vol. 43 No. 4 (2005): 7-29.

Press Office United States Department of Homeland Security. "United States and Canada Implement Safe Third Country Agreement on Asylum." 29 December 2004. U.S. Citizenship and Immigration Services. Retrieved from http://www.uscis.gov/graphics/publicaffairs/newsrels/Safe -12-2994.pdf on 20 June 2006.

Rosciglione, Maria R. Staff Attorney - Casa Vive Buffalo, New York. Interview by Author, 24 July 2006.

Rytina, Nancy F. "Refugee Applicants and Admissions to the United States: 2004 Annual Flow Report." September 2005. United States Department of Homeland Security - Office of Immigration Statistics - Management Directorate. Retrieved from http://www.uscis.gov/graphics/shared/statistics/publications/refugeeflowreport2004.pdf on 2 June 2006. 
Simich, Laura. "Negotiating Boundaries of Refugee Resettlement: A Study of Settlement Patterns and Social Support." The Canadian Review of Sociology and Anthropology, Vol. 40 (2003): 575-591.

Stairs, Denis, David J. Bercusson, Mark Entwhistle, J.L. Granastein, Kim Richard Nossal, and Gordon S. Smith. "In the National Interest: Canadian Foreign Policy in an Insecure World." Canadian Defence and Foreign Affairs Institute, 30 October 2003.

Suhrke, Astri. "Human Security and the Protection of Refugees," in Human Rights. Protection for Refugees, Asylum Seekers, and Internally Displaced Persons: A Guide to International Mechanisms and Procedures, ed. Joan Fitzpatrick. New York: United Nations University Press, 2003, 93-108.

Tazreiter, Claudia. Asylum Seekers and the State: the Politics of Protection in a Security Conscious World. Aldershot: Ashgate Publishing Ltd., 2004.

Towle, Richard. "Human Rights Standards: A Paradigm for Refugee Protection?" in Human Rights and Forced Displacement, (eds.) Anne F. Bayefsky and Joan Fitzpatrick. The Hague: Martins Nijhoff Publishers, 2000, 26-49.

- United States Department of State, Bureau of Population, Refugees and Migration (PRM). Office of Admissions, Refugee Processing Centre (RPC), Fiscal Years 1980-2005. Table 13 Refugee Arrivals: Fiscal Years 1980-2005. Retrieved from http://www.uscic.gov/graphics/shared/statistics/yearbook/y_BK05RA.htm on 3 July 2006.

United Nations High Commissioner for Refugees. "1951 Convention Relating to the Status of Refugees." 28 July 1951. Retrieved from http://www.unhchr.ch/html/menu3/b/o_c ref.htm on 1 February 2006,1 .

United Nations High Commissioner for Refugees: "Number of Asylum Seekers Halved Since 2001 says UNHCR." Press Release UNHCR, Geneva, 17 March 2006.

Van Selm, Joanne. "Refugee Protection, Polices and Security Issues," in Human Rights, Protection for Refugees, Asylum Seekers, and Internally Displaced Persons: A Guide to International Mechanisms and Procedures, ed. Joan Fitzpatrick. New York: United Nations University Press, 2003, 66-92.

White House, The - Office of the Press Secretary. "US-Canada Smart Border/30 Point Action Plan." 6 December 2002. Retrieved from http://www.whitehouse.gov/news/releases/2002/12/2002/2061 .html on 20 July 2006.

Whittaker, David J. Asylum Seekers and Refugees in the Contemporary World. New York: Routledge, 2005. 